\title{
The Effect of OPRM1 rs648893 Gene Polymorphism on Opioid Addiction in an Iranian population in Zabol: A Case-Control Study
}

\author{
Alireza Rezaeifar ${ }^{*}$, Fatemeh Dahmardeh ${ }^{2}$ \\ 'Department of Clinical Biochemistry, School of Medicine, Zabol University of Medical Sciences, Zabol, Iran \\ ${ }^{2}$ Department of Biology, Faculty of Sciences, University of Zabol, Zabol, Iran
}

\section{*Correspondence to Alireza Rezaeifar, Department of Clinical Biochemistry, School of Medicine, Zabol University of Medical Sciences, Zabol, Iran, Tel: 09151442939 \\ Email: ar_rezaeifar@zbmu.ac.ir}

Received September 10, 2019 Accepted November 24, 2019 Published online December 31, 2019

\begin{abstract}
Introduction: Opioid addiction $(\mathrm{OA})$ is a neurologically life-threatening challenge associated with socioeconomic and health concerns for individuals and society. The addictive drugs trigger neuromodulators and neurotransmitters through the opioid receptors and corresponding endogenous peptide ligands. In addition, drug addiction is reportedly related to the mu-opioid receptor (OPRM1) encoding gene and its variants. According to the role of the rs648893 polymorphism of the OPRM1 gene in numerous disorders, it has been suggested as a candidate associated with drug addiction. The present case-control study was conducted to evaluate the role of OPRM1 rs648893 polymorphism in the OA risk.

Methods: To this end, the rs648893 polymorphism was genotyped by tetra amplification refractory mutation system-polymerase chain reaction among 160 Iranian subjects consisting of 105 OA cases and 155 controls.

Results: According to our findings, there was no significant association between OA and the OPRM1 rs648893 gene polymorphism. Moreover, a marginally insignificant difference was found between OA cases and controls in accordance with the allelic frequencies $(P=0.05)$

Conclusion: In general, our results reported no association between OPRM1 rs648893 gene polymorphism and $\mathrm{OA}$ although further research among various ethnicities with larger sample sizes is needed to draw a definite conclusion on the association of rs648893 polymorphism and other OPRM1 intronic variants with opioid and other addictions.

Keywords: Addiction, Opioid receptor, OPRM1, Polymorphism
\end{abstract}

Please cite this article as follows: Rezaeifar A Dahmardeh F, The Effect of OPRM1 rs648893 Gene Polymorphism on Opioid Addiction in an Iranian population in Zabol: A Case-Control Study. Int J Basic Sci Med. 2019;4(4):143147. doi:10.34172/ ijbms.2019.04.

\section{Introduction}

Opioid addiction (OA) as an emerging epidemic has involved a significant number of people around the world in the current century. In the last decade, prescription and non-prescription opioids have been increasingly abused, especially among adults. ${ }^{1}$ Nonetheless, the pathogenesis of addictive disorders and mechanisms of therapeutic approaches have not been well understood yet for drug addicts while serious socioeconomic problems are resulting from using illegal drugs in society. $^{2}$

Opioids are highly addictive narcotics with applications to manage pain. However, opioid abuse can often result in developing overdose, dependence, and tolerance. ${ }^{3}$
They are naturally occurring compounds that physiologically influence the human body. The synthetic, semi-synthetic, and natural opioids apply their anti-nociception impacts on the central nervous system through opioid receptors. ${ }^{4}$

Accordingly, it is essential to scrutinize the genetic parameters involved in $\mathrm{OA}$ with an emphasize on the detection of new therapeutic targets, probably finding the genetic biomarkers of OA risk, and thus developing clinical purposes. ${ }^{5}$

The opioids are able to link with $\mathrm{mu}(\mu)$, kappa ( $\kappa)$, and delta $(\delta)$ opioid receptors, thus changing neurotransmission processes. ${ }^{6}$ Both central and peripheral nervous systems carry such receptors ${ }^{7}$ affected by these opioids, thus resulting in

(C) 2019 The Author(s); Published by Zabol University of Medical Sciences. This is an open-access article distributed under the terms of the Creative Commons Attribution License (http://creativecommons.org/licenses/by/4.0), which permits unrestricted use, distribution, and reproduction in any medium, provided the original work is properly cited. 
analgesia, tolerance, reward, and dependence. ${ }^{8}$

Almost all opiates have primarily high affinity to the $\mu$-opioid receptor, which is originally an active binding site of endogenous and exogenous opioid drugs and peptides. $^{9}$

Further, opioid receptor genes, due to genetic variations, can affect the structure, function, and expression of the receptors, thus leading to decreased or increased risk of opioid dependency. ${ }^{10,11}$

The opioid dependence as medical and social concerns has affected people around the world, including Iran. ${ }^{12}$ This highlights the necessity of further research in order to uncover genetic variables contributing to $\mathrm{OA}$ development, to show the possible genetic association, to raise the neurobiological knowledge of opioid dependence, and finally, to produce the analgesics with higher effectiveness and minimum side effects.

There are many documents on the importance of different genes related to the endogenous opioid system involved in the OA risk. ${ }^{13}$ Although the association between the $\mathrm{OA}$ and polymorphisms in opioid receptor genes has been reported among Iranian population, ${ }^{2}$ there is no study regarding the correlation of OPRM1 gene polymorphism and susceptibility to OA. Intronic sequences can be involved in alternative DNA splicing. The rs648893 $(\mathrm{C} / \mathrm{T})$ polymorphism is located at the third intron of the OPRM1 gene, and some studies have previously reported the effect of this polymorphism on numerous disorders. ${ }^{14,15}$ Therefore, this study was the first one to examine the association of the OPRM1 rs648893 gene polymorphism and $\mathrm{OA}$ in an Iranian population.

\section{Materials and Methods}

Study Population

The study was conducted on 105 OA subjects, including 9 females and 96 males, who referred to the Center for Drug Addiction Treatment in Zabol, Sistan and Baluchestan province, Iran. Their drug dependency was recognized on the basis of the Diagnostic and Statistical Manual of Mental Disorders and the International Statistical Classification of Diseases. ${ }^{16,17}$ The exclusion criteria were major psychiatric disorders affecting neurotransmitter systems. ${ }^{16,17}$ On the other hand, 155 self-reported cases, including 26 females and 129 males, with no history of drug abuse and major psychiatric disorders were included as controls. All samples represented a willingness to participant in the study and signed written consent form.

\section{DNA Extraction and Genotyping}

The blood samples were taken from the research units and maintained at $-20^{\circ} \mathrm{C}$ until testing. The salting-out method was employed to extract genomic DNA.

Then, the samples were genotyped by the tetra amplification refractory mutation system-polymerase chain reaction (ARMS-PCR). The primers were designed (Table 1) by the online Soton website (http://primer1. soton.ac.uk/primer1.html). Next, the genes were amplified by the PCR process using a mixture with the $20-\mu \mathrm{L}$ final volume, containing $1 \mu \mathrm{L}$ of $\mathrm{F} / \mathrm{R}$ primer, $10 \mathrm{~mL}$ of $2 \times$ Taq PCR Master Mix (Genetbio, Denmark), $1 \mu \mathrm{L}$ of template DNA, and $5 \mu \mathrm{L}$ of water. The thermal program of Thermocycler was 30 -second denaturation at $94^{\circ} \mathrm{C}$, 30 -second annealing at $67^{\circ} \mathrm{C}$, and 50 -second extension at $72^{\circ} \mathrm{C}$ within 30 cycles. The DNA products were run on a 3\% agarose gel electrophoresis, stained by the green viewer, and the resulting gel pictures were obtained by the Life Technologies E-gel imager instrument (Figure 1). The randomly repeated genotyping for about $20 \%$ of the samples showed no mistake in genotyping.

\section{Statistical Analysis}

The collected data were statistically analyzed by SPSS software, version 20. The Hardy-Weinberg equilibrium was explored for study groups (OA patients and controls) using the Chi-square test. The association of rs648893 polymorphism with OA was examined by logistic regression analysis through calculating a 95\% confidence interval (CI) and the odds ratio (OR) at the statistically significant level of $P<0.05$.

\section{Results}

The frequency of OPRM1 rs648893 genotypes among the study populations is shown in Table 2. No significant deviation from Hardy-Weinberg equilibrium was found in the SNP data for cases and controls.

According to Table 2, the frequencies of TT (ancestral), TC, and CC genotypes of OPRM1 rs648893 were $80 \%$, $18.1 \%$, and $1.9 \%$ in cases versus $88.4 \%, 11 \%$, and $0.6 \%$ in controls, respectively. Based on logistic regression findings, the OA showed no significant association with

Table 1. Primers Sequences

\begin{tabular}{|c|c|c|}
\hline Primer Name & Primer Sequence $5^{\prime} \rightarrow 3^{\prime}$ & PCR Product (bp) \\
\hline Forward outer primer & 312 TCTGATCATTTCTGTAGCTGGTCACACA 339 & \multirow{2}{*}{343} \\
\hline Reverse outer primer & 654 GACTAAGCAAGCAAGTAGGTTGCTTTGC 627 & \\
\hline $\begin{array}{l}\text { Forward inner primer } \\
\text { (C allele) }\end{array}$ & 476 TGTGTACTGCAGTCTGGTCCCATAGC 501 & 180 \\
\hline $\begin{array}{l}\text { Reverse inner primer } \\
(T \text { allele) }\end{array}$ & 526 СТАСТСССАААТСССАСАAGGСАСТА 501 & 215 \\
\hline
\end{tabular}

Note. PCR: Polymerase chain reaction. 
Table 2. The Frequency of Alleles and Genotypes of OPRM1 rs648893 Polymorphism in Case and Control Groups

\begin{tabular}{lcccc}
\hline \multicolumn{1}{c}{ OPRM1, $\mathbf{r s 6 4 8 8 9 3}$} & $\begin{array}{c}\text { Case } \\
(\mathbf{n = 1 0 5})\end{array}$ & $\begin{array}{c}\text { Control } \\
(\mathbf{n = 1 5 5 )}\end{array}$ & $\boldsymbol{P}$ Value & OR (95\% CI) \\
\hline TT $(\%)$ & $84(80)$ & $137(88.4)$ & 0.1 & $1.8(0.9-3.7)$ \\
TC $(\%)$ & $19(18.1)$ & $17(11)$ & 0.3 & $3.3(0.3-36.5)$ \\
CC $(\%)$ & $2(1.9)$ & $1(0.6)$ & 0.07 & $1.9(0.9-3.7)$ \\
Dominant (TC+CC vs. TT) & & & 0.4 & $3(0.3-33.4)$ \\
Recessive (CC vs. TT+TC) & $187(89)$ & $291(93.9)$ & & Reference \\
T $(\%)$ & $23(11)$ & $19(6.1)$ & 0.05 & $1.9(1-3.5)$ \\
C $(\%)$ & & & \\
\hline
\end{tabular}

Note. OPRM1: Mu-opioid receptor; OR: odds ratio; $\mathrm{Cl}$ : confidence interval.

the OPRM1 rs648893 gene polymorphism. However, the higher frequency of $\mathrm{TC}+\mathrm{CC}$ genotype versus TT was found in cases in the dominant model compared to the OA group although it was not significant $(P=0.07)$. Moreover, there were marginally insignificant differences in rs648893 allele distributions between controls and cases $(P=0.05)$.

\section{Discussion}

Drug addiction as one of the life-threatening disorders in the nervous system is affected by environmental, behavioral, and genetic factors. ${ }^{18}$ The drug dependence has been reportedly shown to be significantly affected by genetic factors according to family, twin, and adoption investigations. ${ }^{19}$ Recent studies have revealed the interactions between the genetics of complex disorders and certain variants significantly affecting the OA risk, which are probably more ready in many replication studies. $^{20}$

Regarding the effectiveness of drug addiction treatment, the drug addiction risk and the interpersonal variations depend on various genetic factors. ${ }^{21}$ There are reports on the association between drug addiction and the polymorphisms of some genes such as those related to

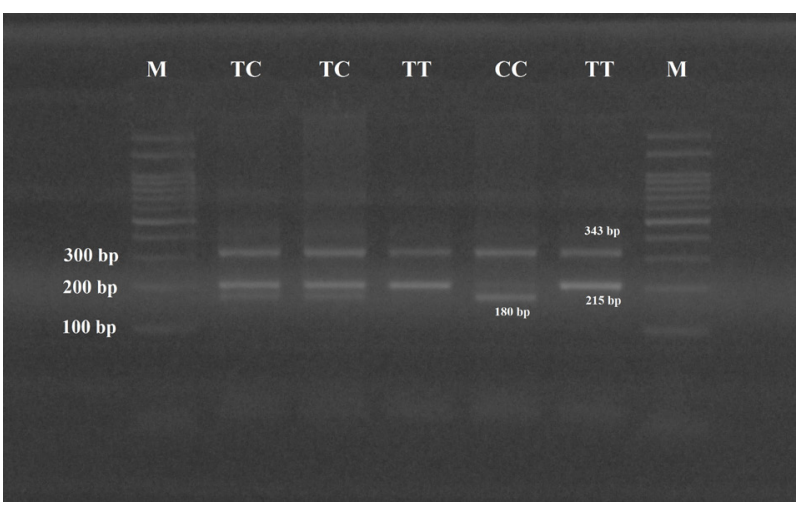

Figure 1. Tetra Amplification Refractory Mutation System-Polymerase Chain Reaction Results for OPRM1-rs648893 Polymorphism. M: 100 bp DNA marker. opioid receptors and ligands. ${ }^{22}$

The opioid $\mu$-receptor encoded by the OPRM1 gene on chromosome 6q24-q25 not only can regulate the analgesic response to pain but also can control the rewarding impacts of different addictive drugs such as opioids and nicotine, as well as alcohol consumption. ${ }^{23}$

Studies on the numerous ethnic groups through the genome sequencing of the OPRM1 gene reported 3324 polymorphisms occupied a $200-\mathrm{kb}$ area on chromosome 6q24-q25 (http://www.1000genomes.org). The frequency of many of such polymorphisms is very low with restricted relevance in the populations. However, the global populations have exhibited minor allele frequencies $>1 \%$ for 1395 genetic variants. The sensitivity to opioids can be significantly affected by inter-individual differences in the OPRM1 gene.

Additionally, the OPRM1 SNPs have been indicated to be important in mediating differences in the OA, which might be related to opioid dependence and ethnic variations in opioid dependence. ${ }^{24}$

Although there is a strong association between OPRM1 exonic SNPs and the risk of opioid dependency, ${ }^{18,25-27}$ there are a few studies regarding the association between $O P R M 1$ intronic SNPs and the risk of opioid dependency. ${ }^{28}$ Moreover, previous results showed an association between OPRM1 intronic SNPs and heroin dependency. ${ }^{29}$ According to Zhang et al, the intronic variants of the OPRM1 gene including rs648893 polymorphism have roles in susceptibility to alcohol and drug dependency in European populations. ${ }^{15}$

Based on the literature review, this is the first study to evaluate the effect of OPRM1 rs648893 polymorphism on the $\mathrm{OA}$ in an Iranian population. Although no association was found between the OA and the OPRM1 rs648893 gene polymorphism. The distribution of the rs648893 allele suggested slightly significant differences between OA cases and healthy controls $(P=0.05)$. Arias et al evaluated the association between rs648893 and suicide-associated outcomes in 426 European-Americans and reported no genotypic/allelic association with phenotypes of suicideassociated outcomes. ${ }^{30}$ In consistent to our results, Xuei 
et al found no significant association between rs648893 polymorphism and drug or alcohol dependency among European Americans. ${ }^{31}$

\section{Conclusion}

The vulnerability to reliance on substance can be affected by OPRM1 genetic variation, which can influence the treatment response to opioid antagonists. According to the results of this study, there was no significant association between the OA and the OPRM1 rs648893 gene polymorphism. However, further research on various ethnicities and with larger sample sizes is needed to draw a definite conclusion on the association between rs648893 polymorphism and other OPRM1 intronic variants with opioids and other addictions.

\section{Ethical Approval}

The Ethics Committee of Zabol University approved our research project with the code of IR.UOZ.Rec.1393.01 according to the Declaration of Helsinki.

\section{Conflict of Interest Disclosure}

We have no conflict of interests.

\section{Informed Consent}

The participants provided written informed consent.

\section{Funding/Support}

This study was supported by the university of zabol , Zabol, Iran.

\section{Authors' Contribution}

AR: the conception and design of the study, data analysis, and manuscript preparation

FD: data collection

\section{Acknowledgment}

This research was supported by the University of Zabol, Iran. We would like to thank all the people and colleagues who helped us with this project.

\section{References}

1. Mistry CJ, Bawor M, Desai D, Marsh DC, Samaan Z. Genetics of opioid dependence: a review of the genetic contribution to opioid dependence. Curr Psychiatry Rev. 2014;10(2):156-167. doi:10.2174/157340051066614032000 0928

2. Soleimani Asl S, Roointan A, Bergen H, et al. Opioid receptors gene polymorphism and heroin dependence in Iran. Basic Clin Neurosci. 2018;9(2):101-106. doi:10.29252/ nirp.bcn.9.2.101

3. Fishbain D, Johnson S, Webster L, Greene L, Faysal J. Review of regulatory programs and new opioid technologies in chronic pain management: balancing the risk of medication abuse with medical need. J Manag Care Pharm.
2010;16(4):276-287. doi:10.18553/jmcp.2010.16.4.276

4. Fornasari D. Pain mechanisms in patients with chronic pain. Clin Drug Investig. 2012;32 Suppl 1:45-52. doi:10.2165/11630070-000000000-00000

5. Reed B, Butelman ER, Yuferov V, Randesi M, Kreek MJ. Genetics of opiate addiction. Curr Psychiatry Rep. 2014;16(11):504. doi:10.1007/s11920-014-0504-6

6. Narita M, Funada M, Suzuki T. Regulations of opioid dependence by opioid receptor types. Pharmacol Ther. 2001;89(1):1-15. doi:10.1016/s0163-7258(00)00099-1

7. Zhang H, Kranzler HR, Yang BZ, Luo X, Gelernter J. The OPRD1 and OPRK1 loci in alcohol or drug dependence: OPRD1 variation modulates substance dependence risk. Mol Psychiatry. 2008;13(5):531-543. doi:10.1038/ sj.mp. 4002035

8. Stein C. Opioid receptors. Annu Rev Med. 2016;67:433451. doi:10.1146/annurev-med-062613-093100

9. Contet C, Kieffer BL, Befort K. Mu opioid receptor: a gateway to drug addiction. Curr Opin Neurobiol. 2004;14(3):370-378. doi:10.1016/j.conb.2004.05.005

10. Sharafshah A, Fazel H, Albonaim A, et al. Association of OPRD1 gene variants with opioid dependence in addicted male individuals undergoing methadone treatment in the north of Iran. J Psychoactive Drugs. 2017;49(3):242-251. doi:10.1080/02791072.2017.1290303

11. Crist RC, Doyle GA, Kampman KM, Berrettini WH. A delta-opioid receptor genetic variant is associated with abstinence prior to and during cocaine dependence treatment. Drug Alcohol Depend. 2016;166:268-271. doi:10.1016/j.drugalcdep.2016.07.008

12. Majdzadeh R, Feiz-Zadeh A, Rajabpour Z, et al. Opium consumption and the risk of traffic injuries in regular users: a case-crossover study in an emergency department. Traffic Inj Prev. 2009;10(4):325-329. doi:10.1080/15389580902995380

13. Kreek MJ, Levran O, Reed B, Schlussman SD, Zhou Y, Butelman ER. Opiate addiction and cocaine addiction: underlying molecular neurobiology and genetics. J Clin Invest. 2012;122(10):3387-3393. doi:10.1172/jci60390

14. Ding S, Chen B, Zheng Y, Lu Q, Liu L, Zhuge QC. Association study of OPRM1 polymorphisms with Schizophrenia in Han Chinese population. BMC Psychiatry. 2013;13:107. doi:10.1186/1471-244x-13-107

15. Zhang H, Luo X, Kranzler HR, et al. Association between two mu-opioid receptor gene (OPRM1) haplotype blocks and drug or alcohol dependence. Hum Mol Genet. 2006;15(6):807-819. doi:10.1093/hmg/ddl024

16. Demetrovics Z, Varga G, Szekely A, et al. Association between Novelty Seeking of opiate-dependent patients and the catechol-O-methyltransferase Val158Met polymorphism. Compr Psychiatry. 2010;51(5):510-515. doi:10.1016/j.comppsych.2009.11.008

17. Voisey J, Swagell CD, Hughes IP, Lawford BR, Young RM, Morris CP. A novel SNP in COMT is associated with alcohol dependence but not opiate or nicotine dependence: a case control study. Behav Brain Funct. 2011;7:51. doi:10.1186/1744-9081-7-51

18. Ahmed M, Ul Haq I, Faisal M, Waseem D, Taqi MM. Implication of OPRM1 A118G polymorphism in opioids addicts in Pakistan: in vitro and in silico analysis. J Mol 
Neurosci. 2018;65(4):472-479. doi:10.1007/s12031-0181123-1

19. Kreek MJ, Nielsen DA, Butelman ER, LaForge KS. Genetic influences on impulsivity, risk taking, stress responsivity and vulnerability to drug abuse and addiction. Nat Neurosci. 2005;8(11):1450-1457. doi:10.1038/nn1583

20. Levran O, Peles E, Hamon S, Randesi M, Adelson M, Kreek MJ. CYP2B6 SNPs are associated with methadone dose required for effective treatment of opioid addiction. Addict Biol. 2013;18(4):709-716. doi:10.1111/j.13691600.2011.00349.x

21. Kreek MJ, Bart G, Lilly C, LaForge KS, Nielsen DA. Pharmacogenetics and human molecular genetics of opiate and cocaine addictions and their treatments. Pharmacol Rev. 2005;57(1):1-26. doi:10.1124/pr.57.1.1

22. Levran O, Yuferov V, Kreek MJ. The genetics of the opioid system and specific drug addictions. Hum Genet. 2012;131(6):823-842. doi:10.1007/s00439-012-1172-4

23. Crist RC, Berrettini WH. Pharmacogenetics of OPRM1. Pharmacol Biochem Behav. 2014;123:25-33. doi:10.1016/j. pbb.2013.10.018

24. Kapur S, Sharad S, Singh RA, Gupta AK. A118g polymorphism in mu opioid receptor gene (OPRM1): association with opiate addiction in subjects of Indian origin. J Integr Neurosci. 2007;6(4):511-522. doi:10.1142/ s0219635207001635

25. Francès F, Portolés $O$, Castelló A, Costa JA, Verdú F. Association between opioid receptor mu 1 (OPRM1) gene polymorphisms and tobacco and alcohol consumption in a
Spanish population. Bosn J Basic Med Sci. 2015;15(2):3136. doi:10.17305/bjbms.2015.243

26. Levran O, Peles E, Randesi M, da Rosa JC, Adelson M, Kreek MJ. The mu-opioid receptor nonsynonymous variant $118 \mathrm{~A}>\mathrm{G}$ is associated with prolonged abstinence from heroin without agonist treatment. Pharmacogenomics. 2017;18(15):1387-1391. doi:10.2217/pgs-2017-0092

27. Vieira CMP, Fragoso RM, Pereira D, Medeiros R. Pain polymorphisms and opioids: an evidence based review. Mol Med Rep. 2019;19(3):1423-1434. doi:10.3892/ mmr.2018.9792

28. $\mathrm{Xu} \mathrm{J}, \mathrm{Lu} \mathrm{Z}, \mathrm{Xu} \mathrm{M}$, et al. A heroin addiction severityassociated intronic single nucleotide polymorphism modulates alternative pre-mRNA splicing of the mu opioid receptor gene OPRM1 via hnRNPH interactions. J Neurosci. 2014;34(33):11048-11066. doi:10.1523/ jneurosci.3986-13.2014

29. Hancock DB, Levy JL, Gaddis NC, et al. Cis-expression quantitative trait loci mapping reveals replicable associations with heroin addiction in OPRM1. Biol Psychiatry. 2015;78(7):474-484. doi:10.1016/j.biopsych.2015.01.003

30. Arias AJ, Chan G, Gelernter J, Farrer L, Kranzler HR. Variation in OPRM1 and risk of suicidal behavior in drugdependent individuals. Am J Addict. 2012;21(1):5-10. doi:10.1111/j.1521-0391.2011.00195.x

31. Xuei X, Flury-Wetherill L, Bierut L, et al. The opioid system in alcohol and drug dependence: family-based association study. Am J Med Genet B Neuropsychiatr Genet. 2007;144b(7):877-884. doi:10.1002/ajmg.b.30531 